\title{
Influence of ibuprofen-arginine on the concentration of amoxicillin in the plasma and tissues of rats with induced periapical lesion
}

\author{
Influência do ibuprofeno arginina sobre a concentração \\ plasmática e tecidual da amoxicilina em ratos \\ com lesão periapical induzida
}

\author{
Giselle Ariana Otto MACKEIVICZ1 ${ }^{1}$ iD https://orcid.org/0000-0002-2559-228X \\ Fernanda Fontoura de CASTRO2 ${ }^{2}$ iD https://orcid.org/0000-0002-1699-0462 \\ Júlia Maria de ROSSI2 iD https://orcid.org/0000-0002-9110-7828 \\ Luis Antônio ESMERINO3 iD https://orcid.org/0000-0003-2495-3490 \\ Fábio André SANTOS ${ }^{3}$ iD https://orcid.org/0000-0003-0347-0270 \\ Márcia Thaís POCHAPSKI² iD https://orcid.org/ 0000-0003-4220-7838
}

\section{ABSTRACT}

Objective: The aim of this study was to evaluate the influence of ibuprofen-arginine on the concentration of amoxycillin in the plasma and periapical tissues of rats with induced apical periodontitis. Methods: Twenty-eight Wistar rats were divided into the following four groups: PL: placebo (saline); AM: amoxycillin (100 mg/kg); IB: ibuprofen-arginine (100 mg/kg); and AM+IB: amoxycillin (100 mg/kg) + ibuprofen-arginine $(100 \mathrm{mg} / \mathrm{kg})$. The animals were submitted to pulp exposure in the first lower left molar, which remained open for fifteen days; this was then closed with composite resin and remained for a further seven days. The treatments were performed using a single dose of the medication (gavage) one hour before taking the samples. Two $\mathrm{mL}$ of blood was collected from the aorta to obtain the blood plasma and the periapical tissue samples, which were homogenized to obtain the supernatant. The samples (plasma and the supernatant periapical tissue) were used to obtain the antibiogram for the analysis of the levels of amoxycillin in the plasma and periapical tissues. Results: The amoxycillin concentration was higher in the AM group compared to the other groups ( $p<0.05$, ANOVA with Tukey's test). Ibuprofen-arginine interfered with plasma concentration of amoxycillin; however, the AM+IB group had a higher concentration of amoxycillin than the PL and IB groups ( $p<0.05$, ANOVA with Tukey's test). The analysis of the supernatant from the periapical tissues showed no significant difference between the groups ( $p>0.05$, Kruskal-Wallis test). Conclusion: Ibuprofen-

1 Universidade Estadual de Ponta Grossa, Programa de Pós-graduação em Ciências da Saúde. Av. Carlos Cavalcanti, 4748, 84030-900, Ponta Grossa, PR, Brasil.

2 Universidade Estadual de Ponta Grossa, Departamento de Odontologia. Ponta Grossa, PR, Brasil. Correspondência para / Correspondence to: MT Pochapski. E-mail: <mpochapski@gmail.com>.

3 Universidade Estadual de Ponta Grossa, Departamento de Análises Clínicas e Toxicológicas. Ponta Grossa, PR, Brasil.

$\boldsymbol{\nabla} \mathbf{v} \boldsymbol{\nabla}$

How to cite this article

Mackeivicz GAO, Castro FF, Rossi JM, Esmerino LA, Santos FA, Pochapski MR. Influence of ibuprofen-arginine on the concentration of amoxicillin in the plasma and tissues of rats with induced periapical lesion. RGO, Rev Gaúch Odontol. 2020;68:e20200040. http://dx.doi. org/10.1590/1981-86372020000403589 
arginine can interfere with the plasma concentration of amoxycillin but this study failed to show the effect of ibuprofen-arginine on the concentration of amoxycillin in the periapical tissues .

Indexing terms: Amoxicillin. Ibuprofen. Microbial sensitivity tests.

\section{RESUMO}

Objetivo: A proposta desta pesquisa foi avaliar a influência do ibuprofeno arginina, sobre a concentração de amoxicilina no plasma e no tecido periapical de ratos com periodontite apical induzida. Métodos: Foram utilizados 28 ratos Wistar, divididos em 4 grupos: PL: placebo (salina); AM: amoxicilina (100mg/kg); IB: ibuprofeno arginina (100mg/kg); e AM+IB: amoxicilina (100mg/kg) + ibuprofeno arginina $(100 \mathrm{mg} / \mathrm{kg})$. Os animais foram submetidos à exposição pulpar do primeiro molar inferior esquerdo que permaneceu aberto por 15 dias e, então, fechado com resina composta, permanecendo por mais 07 dias. Os tratamentos foram realizados com dose única dos medicamentos (gavagem), uma hora antes da obtenção das amostras. Foram coletados $2 \mathrm{~mL}$ de sangue da artéria aorta para a obtenção do plasma sanguíneo e amostras do tecido periapical que foram homogeneizadas para a obtenção do sobrenadante. A partir das amostras (plasma e sobrenadante do tecido periapical) realizou-se o antibiograma para análise da concentração plasmática e tecidual de amoxicilina. Resultados: A concentração de antibiótico foi maior no grupo AM em comparação aos demais grupos $(p<0,05$, ANOVA com Tukey). O ibuprofeno arginina interferiu na concentração plasmática de amoxicilina, no entanto, a concentração de amoxicilina no grupo AM+IB foi maior que nos grupos $P L$ e IB ( $p<0,05$, ANOVA com Tukey). A análise do sobrenadante do tecido periapical não mostrou diferença significativa entre os grupos ( $p>0,05$, Kruskal-Wallis). Conclusão: 0 ibuprofeno arginina pode interferir com a concentração plasmática de amoxicilina, porém o estudo não foi capaz de mostrar o efeito do anti-inflamatório na concentração de amoxicilina no tecido periapical.

Termos de indexação: Amoxicilina. Ibuprofeno. Testes de sensibilidade microbiana.

\section{INTRODUCTION}

The prescription of antibiotics and anti-inflammatories for the control of infection, inflammation and pain is routine in dental practice [1-4]. However, studies have shown that the use of anti-inflammatory drugs concurrently with amoxicillin may be responsible for competition in the concentrations of the latter [5-7].

Interactions can occur when two drugs are concomitantly administered, and this may influence the length of time the drug stays in the body or its efficacy. It is necessary to evaluate possible interactions between these groups of drugs because they may compromise their clinical efficacy $[5,6,8,9]$. The concept of drug interaction is based on the pharmacological or clinical response to the action of a drug, food or chemical substance on the effect of another drug, which is administered either previously or concomitantly to the former $[7,10]$.

Antimicrobial agents designed to treat dental infections are generally used for a longer period of time than other drugs utilized in dental clinics, which may contribute to the emergence of drug interactions $[5,10]$. The main interaction mechanisms that occur with this group of drugs are related to their competitiveness to bind to plasma proteins (drugs with a high degree of binding are most affected) and the ability of some drugs to inhibit cytochrome P450 enzymes. Both these mechanisms can increase the plasma levels of these drugs. Most dental infections are treated with antimicrobials from the penicillin group, metronidazole and tetracycline [10].

Because pulp and periapical pain involve inflammatory processes, the first choice to control this symptomatology are non-steroidal anti-inflammatory drugs (NSAIDs) $[3,11]$. NSAIDs have been shown to be quite effective in controling inflammatory pain and, because of their ability to bind to plasma proteins, they exhibit more efficient access to inflamed tissues [11].

There have been a few studies regarding the interference of NSAIDs in antibiotic concentrations $[5,6,9]$ but there are no reports currently available in the literature evaluating the effect of the administration of ibuprofenarginine on the concentration of amoxicillin in plasma and periapical tissues. Thus, the objective of this study was to evaluate the influence of ibuprofen-arginine on the concentration of amoxicillin in the plasma and periapical tissues of rats with induced apical periodontitis.

\section{METHODS}

This study used twenty-eight male Wistar rats which weighed between 150 and 200 grams. The sample was calculated based on the analysis of the amoxicillin concentration in tissues after the use of anti-inflammatory drugs [9]. Calculations were performed using the mean 
and standard deviation of the concentration of the drug for a $95 \%$ test power. We obtained an effect size of 1.081 for the four experimental groups. A sample size of six animals per group was estimated. Consequently, we chose a sample size of seven animals, foreseeing eventual losses during the experimental procedure. This project was approved by the local ethics committee for the use of animals for research (Process No. 0122016)

\section{Induction of periapical lesion}

For the induction of the periapical lesion, the rats were sedated with an intraperitoneal application of $400 \mathrm{mg} / \mathrm{kg}$ of chloral hydrate. After the animals showed visible signs of sedation (loss of reflex) they were placed on a special operative table that allowed for adequate positioning and containment, maintaining the mouth open. Local infiltrative anesthesia with $2 \%$ mepivacaine with 1:100,000 (0.45 mL) epinephrine (Mepiadre ${ }^{\circledR}$, Nova DFL, Rio de Janeiro, RJ, Brazil) was performed to minimize trans-operative discomfort in the region.

The pulp of the lower left first molar of the rats was exposed by the endodontic opening of the latter using a $1 / 2$ carbide steel drill (Jota do Brasil, Florianópolis, SC, Brazil) mounted on a micro motor (KaVo L-Motor intramatic 181DB and KaVo 20 contra-angle head, Kavo do Brasil Ind. Com. Ltda, Joinville, SC, Brazil) at low rotation speed. The drill was inserted into the distal fossa, located mesially to the distal cusp of the occlusal face of the tooth, at a depth of about $1 \mathrm{~mm}$. The drill was then inserted into the mesial fossa to make an opening to find the distal and mesial canals [12].

The pulp was extirpated using a \#08 $\mathrm{K}$ file (Dentsply Brasil, Petrópolis, RJ, Brazil) in order not to provoke painful symptomatology in the post-operative period. To generate bacterial contamination and to induce the periapical lesion, the teeth remained open with the pulp cavity exposed to the buccal medium for fifteen days. The rats were then anesthetized again with chloral hydrate and the teeth were restored using microhybrid compound resin (Resina Spectrum ${ }^{\circledR}$ THP, Dentsply Brasil, Petrópolis, RJ, Brazil), remaining for a further seven days. The lower right first molar of the animals received no treatment and was used as contralateral control. After this period the animals were medicated and euthanized.

\section{Experimental groups}

After inducing the periapical lesion, the rats were randomly divided into the following four groups $(n=7)$ : PL: placebo (gavage with $1.0 \mathrm{~mL}$ of $0.9 \%$ saline solution); AM: amoxicillin (suspension of $100 \mathrm{mg} / \mathrm{kg}$, Amoxil $\circledast$ oral suspension 250 mg/ 5 ml, GlaxoSmithKline do Brasil Ltda, Rio de Janeiro, RJ, Brazil); IB: ibuprofen-arginine (suspension of $100 \mathrm{mg} / \mathrm{kg}$, Spidufen ${ }^{\circledR}$ 400, Zambon Laboratórios Farmacêuticos Ltda, São Paulo, SP, Brazil); and AM + IB: amoxicillin (100 mg/kg) + ibuprofen-arginine (100 mg/kg).

After the experimental period the animals were treated with a single dose (depending on the group), which was administered intragastrically (gavage) one hour before euthanasia in order to reach the peak of drug concentration for subsequent sample collection.

\section{Obtaining samples}

The euthanasia of the animals was performed after desensitization by injection with chloral hydrate, in order to depress the central nervous system and produce unconsciousness, followed by exsanguination, leading to death.

Blood samples $(2 \mathrm{~mL}$ ) were obtained from the aortic artery. The blood was withdrawn with a sterile syringe and the samples were then placed in sterile plastic tubes; the blood clots were removed in a water bath at 37 ${ }^{\circ} \mathrm{C}$. The blood samples were subsequently centrifuged for ten minutes at 3,500 rpm, and three $30 \mathrm{uL}$ aliquots of the blood plasma of each animal were removed.

The mandibles of the rats were removed, separated into two hemimandibles, and dissected using a scalpel handle with a No.15 Bard-Parker blade. This procedure was performed so that the bone at the area of the lesion could be analyzed. The material was placed in properly labeled containers for subsequent $X$-rays [12].

\section{Radiographic analysis of formation of periapical lesion}

In order to verify if the periapical lesion had formed, a radiograph of the mandibles of the rats was performed using a Gnatus radiograph, model Timex-70 ${ }^{\circledR}$ (Gnatus Equipamentos Médico-Odontológicos Ltda, Ribeirão Preto, SP, Brazil). The radiographic film used was DF-58 
Ultra-speed $^{\circledR}$ Carestream (Carestream Health, São Paulo, SP, Brazil), $30 \times 40 \mathrm{~mm}$ and D speed. The beam-film distance was $20 \mathrm{~cm}$, with a 0.64 second exposure, and the film was revealed and fixed in a darkroom for $1.5 \mathrm{~min}$. The radiographs were digitalized and the images were evaluated by a single examiner using ImageJ software (https://imagej. nih.gov/ij/) for the measurement of the radiolucent area in the periapical region of the tested teeth (with induced lesion) and the control teeth (without induced lesion).

\section{Analysis of amoxicillin concentration in plasma and tissues}

A standard curve was constructed with known concentrations of amoxycillin to analyze and measure the diameter of the inhibition halos that formed. By interpolating the data obtained in a linear regression model it was possible to determine the concentration of amoxicillin in each sample.

\section{Plasma antibiogram}

The blood plasma of the rats was used to perform the antibiogram in order to confirm the amount of amoxicillin in the plasma of the different groups. Filter paper discs containing $10 \mathrm{uL}$ of the animals' plasma were placed in Petri dishes containing Mueller-Hinton agar inoculated with $108 \mathrm{CFU} / \mathrm{ml}$ of Staphylococcus aureus ATCC® 25923 (equivalent to a 0.5 McFarland standard solution). These dishes were incubated in an oven at 33$35^{\circ} \mathrm{C}$ for $16-18$ hours. After this period, two trained and calibrated examiners measured the inhibition halos using a digital caliper (Mitutoyo ${ }^{\circledR} 150 \mathrm{~mm}$, resolution $0.01 \mathrm{~mm}$, ref 500-196-30b, Mitutoyo Sul Americana Ltda, Suzano, SP, Brazil).

\section{Periapical tissues antibiogram}

The mandibles of the animals were sectioned vertically from the center of the crown of the lower second molar up to $3 \mathrm{~mm}$ above the lower border of the mandible, followed by a horizontal cut to the mesial of the lower first molar, using double-faced steel discs $(0.10 \times 22 \mathrm{~mm})$ (KG Sorensen, Cotia, SP, Brazil) in a mandrel adapted to a straight part with a micromotor.
The samples were subsequently placed in 15 $\mathrm{ml}$ Falcon tubes containing $2 \mathrm{ml}$ of saline solution. The mandible fragments and the saline solution were triturated in a tissue homogenizer $\left(\mathrm{Ika}^{\circledR} \mathrm{T} 10\right.$ Basic Ultra Turrax, Ika ${ }^{\circledR}$ Werke GMBH \& CO.KG, Staufen, Germany) and then centrifuged for ten minutes at 3,500 rpm. The supernatant was collected with a pipette and dispensed into other 15 $\mathrm{mL}$ tubes.

The supernatant from each animal sample was subjected to four cycles of 120 seconds of freezing in liquid nitrogen at $-170^{\circ} \mathrm{C}$, which were interspersed with periods of 120 seconds of thawing in a water bath at $37^{\circ} \mathrm{C}$, to reduce the number of bacteria present in the pulp chamber/ root canal13. After this procedure, the antibiogram of the periapical tissue supernatant was performed using the same methods employed for the plasma, only adjusting the values according to the weight of the samples.

\section{Data analysis}

The reproducibility of the inter and intra-examiner data was tested by measuring the inhibition halo and the periapical region (radiographs). In terms of the inhibition halo, the measurements of the two different evaluators (inter-examiner) were compared. For the radiographic measurement of the periapical region, two measurements were taken at different times, both performed by the same evaluator (intra-examiner). All the analyses were performed after the previous clarification and discussion about the parameters to be considered during the measurement. The reproducibility analysis was performed using the BlandAltman method and the t-test for a single sample, with zero being the perfect reproducibility, in which there was no difference between the first and second measurements.

For the analysis of the radiographic measurements of the periapical area, the paired t-test (comparison between the test and control sides), and ANOVA and Tukey's post-hoc test (comparison between groups) were used. The analysis of the measurements of halo inhibition in the samples obtained from the plasma and periapical tissues was performed using ANOVA and Tukey's post-hoc test. When the data did not present normal distribution, the non-parametric Wilcoxon test (comparison between the test and control sides), Kruskal-Wallis test (comparison between groups) and Dunn's post-hoc test were used. The significance level was $5 \%$. 


\section{RESULTS}

Figure 1 shows the standard curve considering the mean of the diameters of the inhibition halos and the logarithm of the amoxicillin concentrations, which established the mathematical equation and correlation coefficient ( $r 2$ ). The standard curve that was obtained showed that the higher the concentration of amoxicillin in the plasma, the larger the inhibition halo.

The reproducibility data for the measurements of the periodontal ligament space (intra-examiner) and the inhibition halo measurements were considered valid because they were within the limits of agreement, with no significant difference in the hypothetical value of zero (perfect agreement). The results are shown in figure 2 .

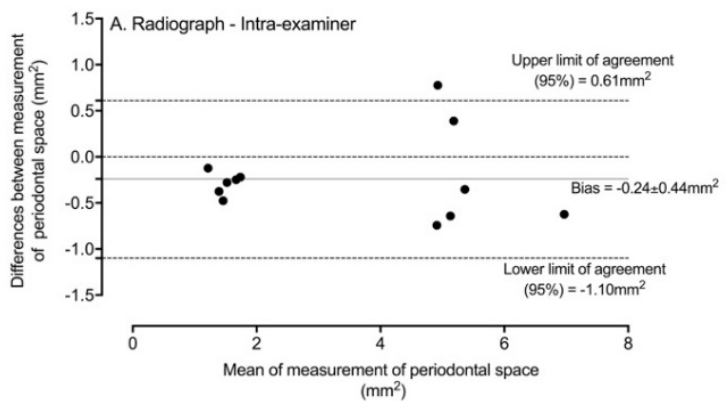

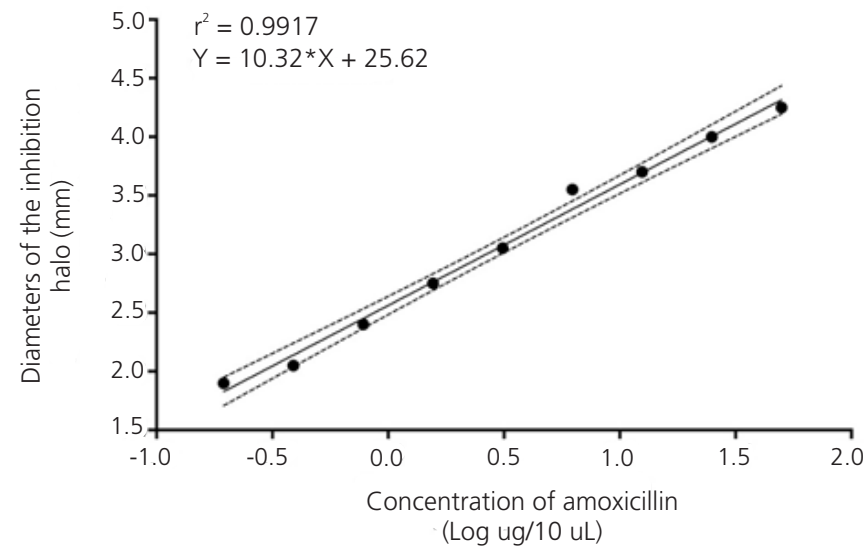

Figure 1. Standard curve of the inhibition halo $(\mathrm{mm})$ and the concentration of amoxicillin (Log ug/10 uL) in plasma. Significant correlation, $\mathrm{p}<0.0001$

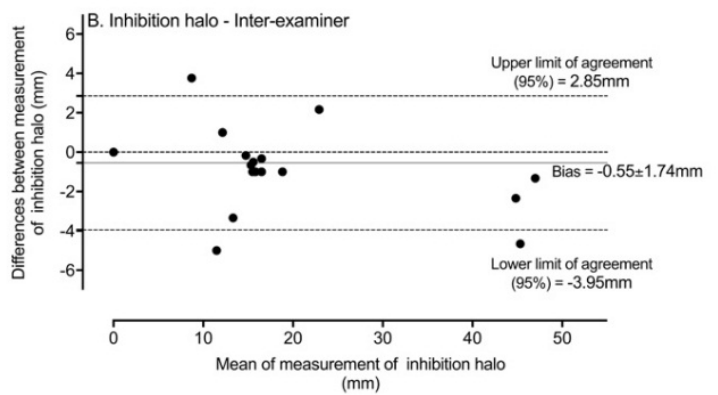

Figure 2. Reproducibility test. Each point represents the mean between the two measurements by the difference between the two. (A) Agreement between the two radiographic measurements of the periodontal space (periapical radiolucent area) in the lower first molars of rats with and without root canal contamination at different times (intra-examiner). (B) Agreement between two measurements of inhibition halo (inter-examiner). Bland-Altman method, most measurements within the confidence interval. Non-significant difference from zero reference value (perfect agreement). (A) $p=0.0797$; (B) $p=0.1015$ (Student's t-test for one sample).

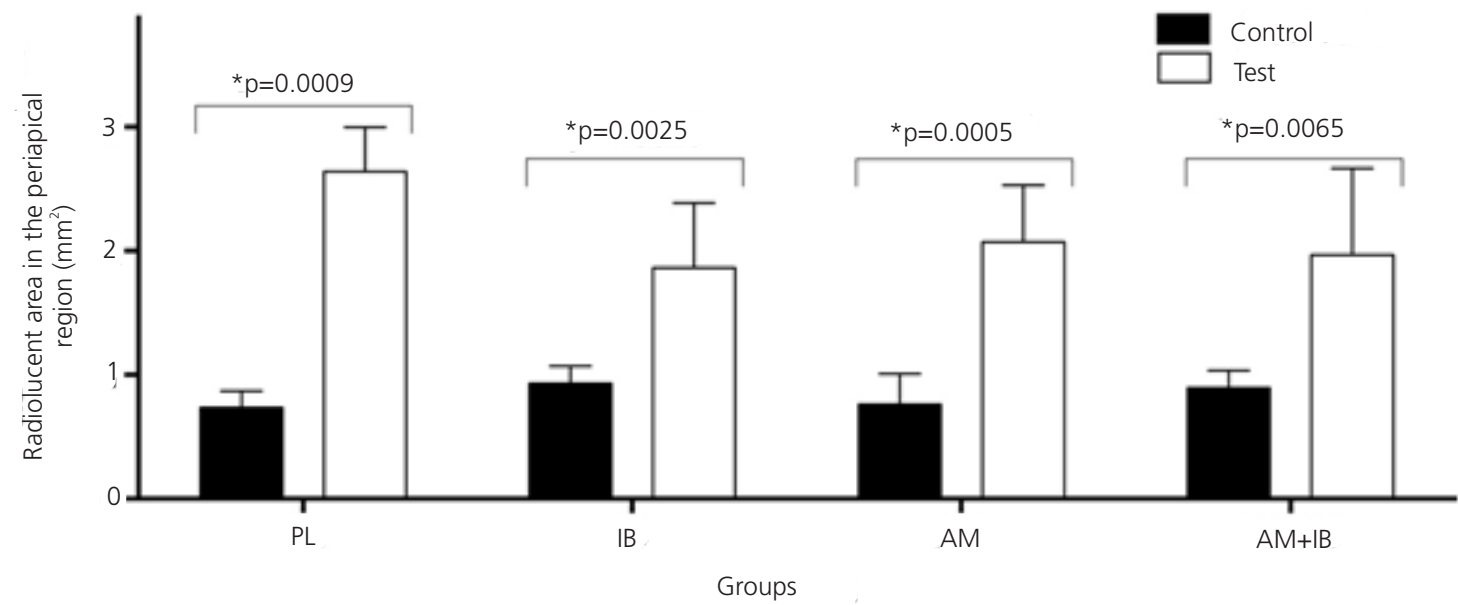

Figure 3. Mean and standard deviation of the radiolucent area in the periapical region. Control: no induction of periapical lesion; Test: induction of periapical lesion in the following different groups: PL: saline; IB: ibuprofen-arginine (100 mg/kg); AM: amoxicillin (100 mg/kg); and AM + IB: amoxicillin $(100 \mathrm{mg} / \mathrm{kg})+\mathrm{lbuprofen}$-arginine $(100 \mathrm{mg} / \mathrm{kg})$. There were significant differences in the radiolucent periapical area between the control and test for all groups $\left({ }^{*} p<0.05\right.$, paired t-test). No differences were observed between the groups considering the control sides $(p=0.1075$, ANOVA) and test $(p=0.1473)$. 
Figure 3 shows the periapical radiolucent areas of the teeth with induced periapical lesion (test) and control (no lesion). The results confirmed that the method was valid regarding the induction of periapical lesions in all the groups compared with the control (significant differences, $p<0.05$ ). There were no differences between the groups, considering the sides with (test) and without (control) induced periapical lesions.

After constructing the standard curve, the concentration of amoxicillin in the plasma was obtained based on the inhibition halo. The results are shown in figure 4. The amoxicillin-treated group showed larger inhibition halos, suggesting higher concentrations of the drug in the plasma than the amoxicillin + ibuprofen-arginine group.

The results regarding the concentration of amoxycillin in the periapical tissues did not show significant differences between the groups, neither for the control nor the test samples. Significant difference was only observed between the test and control teeth for the amoxicillin-treated group (figure 5).

\section{DISCUSSION}

The results of this study showed that ibuprofenarginine interfered with the concentration of amoxicillin in the plasma of rats with periapical lesions. However, when amoxicillin was administered together with ibuprofenarginine the concentration of amoxicillin was lower than when it was used alone. This result shows that the joint use of anti-inflammatory and antibiotic drugs can interfere in the plasma concentration of antibiotics, and consequently affect their efficacy. Previous studies of other types of antiinflammatory drugs have had similar results to those found in our study $[5,6,9]$.

This is the first study in the literature that has evaluated the influence of ibuprofen-arginine on the concentration of amoxicillin in plasma and areas of periapical lesions. The development of the periapical lesion was confirmed by the radiographs; however, the results did not show significant differences between the groups when the concentration of amoxycillin present in the tissues of the areas of the periapical lesion was evaluated. One of the possible reasons for this result was the reduced

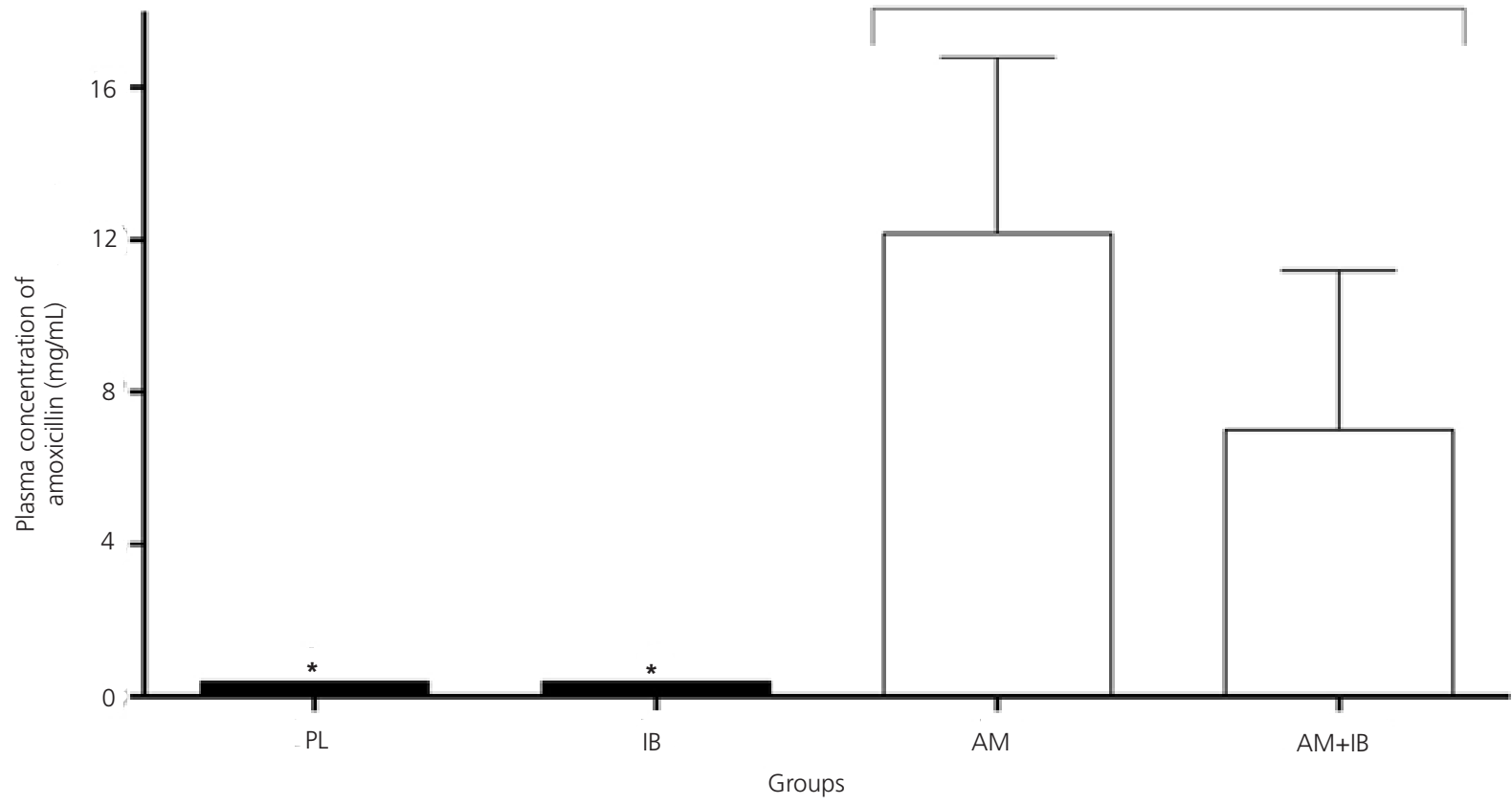

Figure 4. Mean and standard deviation of plasma concentration of amoxicillin ( $\mathrm{mg} / \mathrm{mL})$ in treated animals: PL: saline; IB: ibuprofen-arginine (100 mg/kg); AM: amoxicillin (100 mg/kg); and AM + IB: amoxicillin (100 mg/kg) + ibuprofen-arginine $(100 \mathrm{mg} / \mathrm{kg})$. $\left(^{*}\right) \mathrm{p}<0.05$, significant difference with AM and $\mathrm{AM}+\mathrm{IB} .\left(^{* *}\right) \mathrm{p}<0.05$ between AM and AM + IB. ANOVA with Tukey's post-hoc test. 


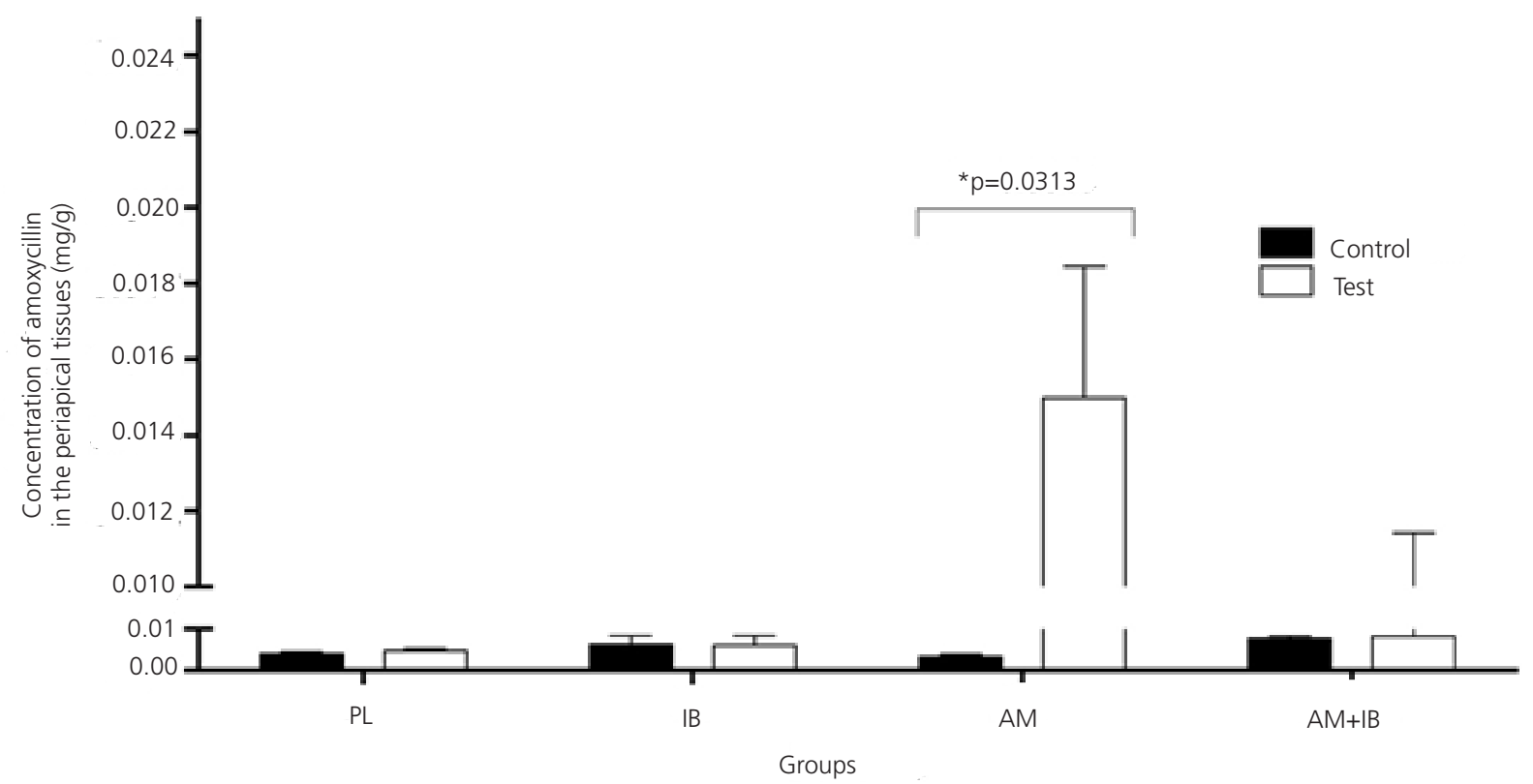

Figure 5. Mean and standard deviation of tissue concentration of amoxicillin ( $\mathrm{mg} / \mathrm{g})$ in treated animals: PL: saline; IB: ibuprofen-arginine (100 mg/kg); AM: amoxicillin $(100 \mathrm{mg} / \mathrm{kg})$; and AM + IB: amoxicillin $(100 \mathrm{mg} / \mathrm{kg})+$ ibuprofen-arginine $(100 \mathrm{mg} / \mathrm{kg})$. There were significant differences in the concentration of amoxycillin in the periapical tissues between the test and control for the group treated with amoxicillin ( ${ }^{*} p<0.05$, Wilcoxon test). No differences were observed between the groups considering the control ( $p=0.2616$, Kruskal-Wallis) and test sides ( $p=0.1899$, Kruskal-Wallis).

size of the periapical lesions and, consequently, the low amount of amoxicillin in the area. The differences in the concentration of amoxicillin were only significant when comparing the areas with and without periapical lesion in the group treated only with amoxicillin. This result was probably due to the larger area of inflammation in the group with periapical lesions. Another factor to be considered was the method used to determine the amoxicillin concentration by means of a standard curve in accordance with the halo measurements regarding $S$. aureus inhibition. The microbiological method is effective in measuring amoxicillin concentrations in body and tissues fluids [6]; however, other techniques have been developed to assess the amount of antimicrobial agents in lowvolume samples more accurately, including mercurimetric, high-performance liquid chromatography, iodometry, optical methods and ultraviolet spectrophotometry [1318]. Nevertheless, these methods are unable to assess whether or not the antibiotic is active. Therefore, methods to detect the activity of antibiotics at low concentrations still need to be established and validated.

The analysis of the possible interaction between antibiotics and anti-inflammatories is of great importance because it is recommended in Endodontics that antibiotics should only be used as a complement to non-surgical endodontic therapy or surgery itself. Antibiotics are reserved for patients with systemic symptoms associated with endodontic infections, which is designed to avoid complications related to drug interactions and the risk of bacterial resistance due to the inadequate prescription of antibiotics $[4,19]$. Considering the model used in the present study, if there is difficulty in providing antibiotics in the area of action then a combination of antibiotics and anti-inflammatories should be avoided and other drug alternatives should be considered.

The routes of administration, absorption and distribution are important factors in the concentration of drugs in plasma and tissues. Absorption is the mechanism of passage of the drug from its area of administration into the bloodstream, and distribution is the mechanism of passage of the drug from the bloodstream into the tissues [8]. In our study, both amoxicillin and ibuprofen-arginine were administered intragastrically (gavage), so the area of absorption was the same as that of amoxicillin. The onset of action of ibuprofen-arginine occurs within approximately 15-30 minutes [20]. Ibuprofen is generally considered to be the prototype of contemporary NSAIDs and has a well documented efficacy and safety profile [21]. For these reasons it was chosen as the NSAID in this study. 
Amoxicillin does not have a high plasma protein binding rate (18\%) and its elimination half-life is approximately one hour. Amoxicillin is easily distributed through tissues and organic liquids, and only 19-33\% of the absorbed fraction is metabolized, essentially by the hydrolysis of the -lactam ring and the formation of amoxycillic acid, which is the corresponding penicillium acid in the residual penicillins [22-25]. In dentistry, amoxicillin is considered to be the first choice antimicrobial for several types of infections; it is recommended for the treatment of oral infections due to its efficacy against most of the isolated microorganisms in dentoalveolar abscesses, and also to promote satisfactory tissue concentrations $[1,2,19]$. For these reasons it was chosen as the antimicrobial in this study.

Because ibuprofen-arginine has a higher plasma protein binding rate, a higher plasma concentration of ibuprofen may occur. Its smaller molecular size causes ibuprofen to pass through the membranes more easily, reaching the bloodstream more quickly. Other factors, such as changes in the physical and chemical characteristics of the products (e.g. pH) caused by the combination of both drugs may facilitate the absorption of one drug and prejudice the effect of the other $[8,20]$. The intestinal absorption of amoxicillin has a passive diffusion component. For some penicillins, intestinal absorption involves the dipeptide, tripeptide or oligopeptide transport systems. These systems consist of two homologous peptide transporters (PEPT1), which are mainly located in the small intestine. This means that amoxicillin is not well absorbed in the stomach; its absorption mostly occurs in the small intestine $[18,23,24]$.

We were unable to state exactly which mechanism ibuprofen interferes with in the plasma concentration of amoxicillin, but we would suggest that there are a number of changes that the concomitant administration of drugs causes in the body. However, this study was unable to identify any alteration in the amoxycillin in the periapical tissues.

\section{CONCLUSION}

The results of this study showed that ibuprofenarginine interfered with the plasma concentration of amoxicillin because when it was administered together with amoxicillin the concentration of the antibiotic was lower than when administered alone. However, in tissue samples from the periapical region, ibuprofen-arginine did not significantly interfere with the tissue concentration of amoxicillin.

\section{Acknowledgments}

This study was financed in part by the Coordination of Higher Education and Graduate Training (CAPES) - Finance Code 001 and Fundação Araucária de Apoio ao Desenvolvimento Científico e Tecnológico do Estado do Paraná.

\section{Collaborators}

MACKEIVICZ GAO, CASTRO FF and ROSI JM, carried out the experiment and wrote the first draft of the manuscript. Esmerino LA, supervised the microbiological tests. SANTOS FA, carried out the statistical analysis and contributed for the final version of the manuscript. POCHAPSKI MT, supervised the methodological steps and participated of the data/results analysis and discussion.

\section{REFERENCES}

1. De-Paula KB, Silveira LS, Fagundes GX, Ferreira MB, Montagner F. Patient automedication and professional prescription pattern in an urgency service in Brazil. Braz Oral Res. 2014;28(1):1-6. http://dx.doi/10.1590/1807-3107BOR-2014.vol28.0041

2. Marra F, George D, Chong M, Sutherland S, Patrick DM. Antibiotic prescribing by dentists has increased: Why? J Am Dent Assoc. 2016;147(5):320-7. http://dx.doi/10.1016/j.adaj. 2015.12.014

3. Smith EA, Marshall JG, Selph SS, Barker DR, Sedgley CM. Nonsteroidal Anti-inflammatory Drugs for Managing Postoperative Endodontic Pain in Patients Who Present with Preoperative Pain: A Systematic Review and Meta-analysis. J Endod. 2017;43(1):7-15. http://dx.doi/10.1016/j.joen. 2016.09.010

4. Segura-Egea JJ, Martin-Gonzalez J, Jimenez-Sanchez MDC, Crespo-Gallardo I, Sauco-Marquez JJ, Velasco-Ortega E. Worldwide pattern of antibiotic prescription in endodontic infections. Int Dent J. 2017;67(4):197-205. http://dx.doi/10. 1111/idj. 12287

5. de Cassia Bergamaschi C, Motta RH, Franco GC, Cogo K, Montan MF, Ambrosano GM, et al. Effect of sodium diclofenac on the bioavailability of amoxicillin. Int J Antimicrob Agents. 2006;27(5):417-22. http://dx. doi/10.1016/j.ijantimicag.2006. 02.005

6. Groppo FC, Simoes RP, Ramacciato JC, Rehder V, de Andrade ED, Mattos-Filho TR. Effect of sodium diclofenac on serum and tissues concentration of amoxicillin and on staphylococcal infection. Biol Pharm Bull. 2004;27(1):52-5. http://dx.doi/10.1248/bpb.27.52 
7. Leao DF, de Moura CS, de Medeiros DS. [Evaluation of potential drug interactions in primary health care prescriptions in Vitoria da Conquista, Bahia (Brazil)]. Cien Saude Colet. 2014;19(1):311-8. http://dx.doi/10.1590/1413-81232014191.2124

8. de Velde F, de Winter BC, Koch BC, van Gelder T, Mouton JW. Non-linear absorption pharmacokinetics of amoxicillin: consequences for dosing regimens and clinical breakpoints. J Antimicrob Chemother. 2016;71(10):2909-17. http://dx. doi/10.1093/jac/dkw226

9. Mattos Filho TR, S. JM, Groppo FC, Motta RH, Perazzo FF. Effect of betamethasone and diclofenac sodium on serum and tissues concentration of amoxicillin. In vivo study in rats. J Appl Oral Sci. 2006;14(5):319-23. http://dx.doi/10.1590/ S1678-77572006000500004

10. Gomez-Moreno G, Guardia J, Cutando A, Calvo-Guirado $\mathrm{JL}$. Pharmacological interactions of anti-microbial agents in odontology. Med Oral Patol Oral Cir Bucal. 2009;14(3):E123-8.

11. Aminoshariae A, Kulild JC, Donaldson M, Hersh EV. Evidencebased recommendations for analgesic efficacy to treat pain of endodontic origin: A systematic review of randomized controlled trials. J Am Dent Assoc. 2016;147(10):826-39. http://dx.doi/10.1016/j.adaj.2016.05.010

12. Teixeira RC, Rubira CM, Assis GF, Lauris JR, Cestari TM, RubiraBullen IR. Radiological and histopathological evaluation of experimentally-induced periapical lesion in rats. J Appl Oral Sci. 2011;19(5):500-4. http://dx.doi/10.1590/S1678-775720 11005000020

13. Mandras N, Allizond V, Bianco A, Banche G, Roana J, Piazza $L$, et al. Antimicrobial efficacy of cryotreatment against Enterococcus faecalis in root canals. Lett Appl Microbiol. 2013;56(2):95-8. http://dx.doi/10.1111/lam.12017

14. Tsikas D, Kayacelebi AA, Hanff E, Mitschke A, Beckmann B, Tillmann HC, et al. GC-MS and GC-MS/MS measurement of ibuprofen in 10-muL aliquots of human plasma and mice serum using [alpha-methylo-(2)H3]ibuprofen after ethyl acetate extraction and pentafluorobenzyl bromide derivatization: Discovery of a collision energy-dependent H/D isotope effect and pharmacokinetic application to inhaled ibuprofen-arginine in mice. J Chromatogr B Analyt Technol Biomed Life Sci. 2017;1043:158-66. http://dx.doi/10.1016/j. jchromb.2016.06.014

15. Bellur Atici E, Yazar Y, Agtas C, Ridvanoglu N, Karliga B. Development and validation of stability indicating HPLC methods for related substances and assay analyses of amoxicillin and potassium clavulanate mixtures. J Pharm Biomed Anal. 2017;136:1-9. http://dx.doi/10.1016/j.jpba.2016. 12.032
16. Abdulla A, Bahmany S, Wijma RA, van der Nagel $B C H$, Koch BCP. Simultaneous determination of nine beta-lactam antibiotics in human plasma by an ultrafast hydrophilicinteraction chromatography-tandem mass spectrometry. J Chromatogr B Analyt Technol Biomed Life Sci. 2017;1060:138-43. http://dx.doi/10.1016/j.jchromb.2017.06.014

17. Kang J, Hossain MA, Park HC, Jang Y, Kim S, Song JY, et al. Rapid determination of beta-lactam antimicrobial resistance in bacteria by a liquid chromatography-mass spectrometrybased method. Anal Bioanal Chem. 2016;408(29):8539-49. http://dx.doi/10.1007/s00216-016-9979-9

18. Wibawa JI, Fowkes D, Shaw PN, Barrett DA. Measurement of amoxicillin in plasma and gastric samples using highperformance liquid chromatography with fluorimetric detection. J Chromatogr B Analyt Technol Biomed Life Sci. 2002;774(2):141-8. http://dx.doi/10.1016/S1570-0232(02)00 179-4

19. Segura-Egea JJ, Gould K, Sen BH, Jonasson P, Cotti E, Mazzoni A, et al. Antibiotics in Endodontics: a review. Int Endod J. 2017;50(12):1169-84. http://dx.doi/10.1111/iej.12741

20. Cattaneo D, Clementi E. Clinical pharmacokinetics of ibuprofen arginine. Curr Clin Pharmacol. 2010;5(4):239-45. http://dx.doi/10.2174/157488410793352012

21. Shin D, Lee SJ, Ha YM, Choi YS, Kim JW, Park SR, et al. Pharmacokinetic and pharmacodynamic evaluation according to absorption differences in three formulations of ibuprofen. Drug Des Devel Ther. 2017;11:135-41. http://dx.doi/10.2147/ dddt.s121633

22. Baglie S, Groppo FC, Filho TR. Tissues pharmacokinetics of amoxicillin. An experimental design in rats. Braz J Infect Dis. 2000;4(4):197-203.

23. Cooreman MP, Krausgrill P, Hengels KJ. Local gastric and serum amoxicillin concentrations after different oral application forms. Antimicrob Agents Chemother. 1993;37(7):1506-9. http://dx.doi/10.1128/AAC.37.7.1506

24. Fraschini F, Scaglione F, Falchi M, Dugnani S, Mezzetti M, Cicchetti $F$, et al. Pharmacokinetics and tissues distribution of amoxicillin plus clavulanic acid after oral administration in man. J Chemother. 1990;2(3):171-7. http://dx.doi/10.10 80/1120009X.1990.11739013

25. Ostrowski M, Wilkowska E, Baczek T. In vivo-in vitro correlation for amoxicillin trihydrate $1000 \mathrm{mg}$ dispersible tablet. Drug Dev Ind Pharm. 2009;35(8):981-5. http://dx. doi/10.1080/03639040902737492

Received on: 16/5/2018 Final version resubmitted on: 21/10/2019 Approved on: 28/7/2020 